\title{
Symmetric and Asymmetric Nexus between Institutional Quality and Sectorial Foreign Direct Investment Inflow in India: A Fresh Insight Using Simulated Dynamic ARDL Approach
}

\section{Faheem Ur Rehman ( $\nabla$ faheem787@yahoo.com )}

Jilin University https://orcid.org/0000-0002-5016-7437

\section{Kazi Sohag}

Ural Federal University named after the first President of Russia B N Yeltsin University Library: Ural'skij federal'nyj universitet imeni pervogo Prezidenta Rossii B N El'cina Zonal'naa naucnaa biblioteka Ejaz Ahmad Kohat University of Science and Technology

\section{Research}

Keywords: Sectorial FDI inflow, Institutional Quality, simulated ARDL dynamic, India

Posted Date: May 6th, 2021

DOl: https://doi.org/10.21203/rs.3.rs-479746/v1

License: (c) (1) This work is licensed under a Creative Commons Attribution 4.0 International License.

Read Full License 
1 Symmetric and Asymmetric Nexus between Institutional Quality and Sectorial Foreign

2 Direct Investment Inflow in India: A Fresh Insight Using Simulated Dynamic ARDL 3 Approach

4 5

6

7

8

17

18

19

20

21

22

23

24

25

26

27
Faheem Ur Rehman*

Laboratory of International and Regional Economics, Graduate School of Economics and Management, Ural Federal University, Russia faheem787@yahoo.com

Kazi Sohag Graduate School of Economics and Management, Ural Federal University, Russia sohagkaziewu@gmail.com

\section{Ejaz Ahmad}

Department of Economics, Kohat University of Science and Technology, Kohat, Pakistan ahmad@uoh.edu.pk

*Corresponding Author: Graduate School of Economics and Management, Ural Federal University, Mira Street, Russia 620002, faheem787@yahoo.com 

Approach

\section{Abstract}

This study investigates the bidirectional causal relationship between institutional quality and aggregated and disaggregated (primary, secondary and services sector) FDI inflow in India by employing new simulated autoregressive distributed lag (SARDL) dynamic techniques, which is an extended version of NARDL and ARDL. The empirical results supports that institutional quality strongly attract aggregated and disaggregated FDI and reversely FDI enhance the quality of institutions. The nexus between FDI inflow and institutional quality is good news for India to enhance the institutional quality and catch-up on advanced economies. The empirical findings detect cointegration and bidirectional causal-relationship between aggregated FDI and institutional quality.

Key Words: Sectorial FDI inflow; Institutional Quality; simulated ARDL dynamic; India

JEL classifications; H5; H54; C22; F2; F21; O17

\section{Introduction}

For enhancement of FDI, the Institutional quality has gained too much interest in last ten years. There are abundant studies that indicate that quality institutions enhance FDI and causes capital mobility in international market (Contractor et al., 2021; Kottaridi et al., 2019). However, there are limited studies on the role of FDI in improving the institutional quality in host countries. Good quality of institutions significantly enhances FDI inflow (Soh et al., 2021; Azzimonti 2019) while without quality of institutions or deficiency in institutional arrangement like law-and-order situation, investors protectionism, political stability, government policies, formal and informal conduct codes can negatively affect investment follow. Institutional quality is interesting for foreign investor because it deceases implementation cost and make doing business easy in host countries. While, Poor institutions impede FDI and can act like a tax, thus increasing the cost of FDI (Camarero et al., 2021; Donghua et al., 2019). Investors are unwilling to invest in countries 
where institutions encourage corruption, nepotism and red tape because these factors increase

62 business operational cost (Cicatiello et al., 2021; Wang et al., 2019). Ryan and Tang (2021)

63 suggested that institution without good governance seems for tax substitution on foreign investors.

64 Piteli (2021) reported that FDI inflow is significantly discouraged due to corruption, worse law

65 and order situation and bureaucratic delay in developing economies. Positive role of FDI in economics has turned a self-evident truth where technological, saving and investment gap is covered by foreign firm through provision of technology and cash to the recipient economy. FDI provide opportunity to local firms for learning from foreign firms either by doing with these firms are watching and infuse a sense of competition in local firms and institutions that boost the productivity as whole of the host country. Nam (2020) suggests that competition in attracting FDI have positive contribution in FDI aspirant countries and call prodigious positive change FDI and introduce to rival recipient countries as race to the top. FDI not only transfer innovation in productive technology, but it also improves the institution quality which contribute to domestic economy. May studies have found corruption relationship with economic openness (Antonietti and Franco, 2021; Challe et al., 2019) but very limited studies have highlighted the impact of FDI on institutional quality.

Junjian (2021) explored the impact of FDI on institutional quality by the channel of demand and supply. Kellard et al., (2021) pointed out that corruption level has been reduced in recipient countries by FDI, and have justified that it is due to good governance and better management which is practiced by foreign investors. Slesman et al., (2021) suggested that advancement in technology (introduced mainly by FDI) and efficient institutions are very important for economic growth. Although FDI and institutional qualities are very important for economic growth, but there is very limited literature on causal relationship of FDI with institutional quality (Tag, 2021). Existing literature have some flaws in understanding the relationship of FDI with institutional quality. First of all, these studies have explained the FDI and institutional quality relationship by employing aggregated data of FDI, which does not provide blue print of causal relation of FDI with institutional quality. Secondly, these studies focused on only one aspect of institution quality i.e political risk and corruption for explaining the impact of institutional quality and FDI. Thirdly these studies are based on cross countries analysis that leads to ambiguous results due to existence of heterogeneity issues (Heavilin and Songur, 2020). 
91 On these grounds this study employ a set of indictor for evaluating the overall impact of 92 institutional quality on sectorial FDI and reversely how sectorial FDI effect quality of institution in India with focusing on single country analysis for formulation of policy based on strong foundations. As per our knowledge, no empirical study is conducted on bidirectional causality of quality of institution and sectorial FDI of any sector i.e. agriculture, industrial and services. For this study simulated ARDL technique are applied for investigating the long run and short run bidirectional causality of institutional quality and sectorial FDI in India. The aim of this new simulated ARDL dynamic model was to reduce the issues of the orthodox ARDL model in examining long-run and short-run diverse model specifications.

100

The present study is organized as follows: The trend of FDI and quality of institutions in India is explained in Section 2. In Section 3, the relationship between aggregated and disaggregated FDI inflow and institutional quality in Literature Review. This is followed by a detailed description of the econometric methodology and sources of the data. Next empirical results of the study are evaluated, and finally, conclusions are presented and some policy recommendations are made.

\section{FDI Trends and Institutional quality in India}

This section deals with trends and FDI inflow structural pattern in India. FDI inflow distribution in India have two dimensions: first government prevailed treatment of FDI inflow in specified sector and secondly it shows preferential investment of multinational cooperation among different sector. India, the second largest country of the world by population, has great growth potential and is very suitable for FDI. Institutional quality of India is good in Asian economies that is the reasons that it has achieved remarkable achievement in FDI attraction from the FY-2008 and onward (Cai 2016; Forte and Moura, 2013). FDI inflow in India has increased by $55 \%$ from US \$ 231.37 billion to 358.29 in period 2008-14 to 2014-2019 (Reddy, 2019). However still it needs improvement as 115

\section{Table 1: \% of various economic groups in total FDI}

\begin{tabular}{|l|l|l|l|l|l|}
\hline Period & Mining & Manufacturing & Utilities & Trade & Transport \\
\hline $1980-1984$ & 24.4 & 56.3 & 4.7 & 5.9 & 2.1 \\
\hline $1985-1989$ & 42.1 & 19.1 & 1.2 & 29.2 & 4.7 \\
\hline
\end{tabular}




\begin{tabular}{|l|l|l|l|l|l|}
\hline $1990-1994$ & 21.6 & 16.9 & 9.3 & 35.7 & 2.5 \\
\hline $1995-1999$ & 7.7 & 21.6 & 30.9 & 21.7 & 6.0 \\
\hline $2000-2004$ & 35.7 & 12.7 & 6.6 & 9.3 & 35.7 \\
\hline $2005-2009$ & 44.2 & 18.2 & 8.5 & 7.9 & 5.2 \\
\hline $2010-2014$ & 41.7 & 19.1 & 7.4 & 8.6 & 6.1 \\
\hline $2015-2019$ & 43.9 & 18.5 & 7.9 & 9.3 & 6.6 \\
\hline
\end{tabular}

Source: Authors own calculations.

Note: Mining: mining oil and gas and quarrying, Manufacturing: manufacturing Utilities: utilities and power, Trade: trade and commerce, Transport: transport, communications, storage, social, financial, and personal services

\section{Table 2: Sector-wise performance Index of FDI}

\begin{tabular}{|l|l|l|l|}
\hline Period & Primary & Secondary & Tertiary \\
\hline $1980-1984$ & 59.62 & 4.87 & 0.09 \\
\hline $1985-1989$ & 81.57 & 1.08 & 0.19 \\
\hline $1990-1994$ & 41.47 & 1.03 & 0.33 \\
\hline $1995-1999$ & 17.67 & 1.43 & 0.17 \\
\hline $2000-2004$ & 15.07 & 0.94 & 0.67 \\
\hline $2005-2009$ & 14.91 & 0.97 & 0.71 \\
\hline $2010-2014$ & 14.88 & 0.89 & 0.93 \\
\hline $2015-2019$ & 13.27 & 0.88 & 0.92 \\
\hline
\end{tabular}

Source: Authors own calculations.

\section{Table 3: Indian Quality of Institution Index (1980-2019)}

\begin{tabular}{|l|l|l|l|l|l|}
\hline & IIQ & WR & Min Value & Max Value & SD \\
\hline $\begin{array}{l}\text { Profile of } \\
\text { Investment }\end{array}$ & 6.31 & 113 & 3.11 & 7.93 & 1.42 \\
\hline Law \& orders & 6.17 & 104 & 2.5 & 7.31 & 0.67 \\
\hline
\end{tabular}




\begin{tabular}{|l|l|l|l|l|l|}
\hline $\begin{array}{l}\text { Political } \\
\text { Stability }\end{array}$ & 8.16 & 97 & 2.47 & 10.37 & 2.19 \\
\hline Corruption & 3.41 & 101 & 1.97 & 5.7 & 0.31 \\
\hline Accountability & 5.53 & 111 & 1.05 & 8.97 & 1.17 \\
\hline $\begin{array}{l}\text { Quality of } \\
\text { Bureaucracy }\end{array}$ & 6.73 & 72 & 3.31 & 5.51 & 0.10 \\
\hline $\begin{array}{l}\text { Composite } \\
\text { Index of } \\
\text { Institution }\end{array}$ & 6.61 & 119 & 2.91 & 7.69 & 0.98 \\
\hline
\end{tabular}

122

123

124

125

126

127

128

129

130

131

132

Source: Authors own calculations.

IIQ stands for institutional quality index, GR: Global Ranking

Table 1 indicate that in last 30 years Indian FDI has significantly changed from one sector to other in last 30 years. In 1980s foreign investors were interesting in investing in manufacturing, quarrying and mining sector and these sectors share was greater than 80\% from 1980 to 1984 . Shares of these sector was dropped to $30 \%$ from 1995 to 1999 and then raised to $40 \%$ in 2000 to 2004. The radical decline in manufacturing sector FDI was initially replaced by commerce, mining and quarrying sector and after that replaced by personal services, social services, financial, communication and transportation. This proved that sectorial preferences continuously changed in Indian FDI in last thirty years. By the same way pre- and post-reform analysis shows a significant variation in sectorial FDI. In the pre-reform period manufacturing, mining and quarrying sector shares drastically decreased and services sector shares has increased. Services sector FDI shares has increased from $2.2 \%$ to $45 \%$ from the period 1980-1994 to 1995-2010. For performance analysis of FDI in pre and post reform index is calculated that shows relative sectorial FDI contribution in total GDP as mentioned in table 2. A sector with value greater than one, means that it has gained more FDI as compared to relative economic size of that sector, while a value:

$$
S F P I=\frac{F D I_{i} / F D I_{t}}{G D P_{i} / G D P_{t}}
$$

Where $\mathrm{FDI}_{\mathrm{i}}$ represents of FDI in sector $\mathrm{I}_{\text {, FDI }}$ means total FDI, GDP $\mathrm{I}_{\mathrm{I}}$ means I sector GDP and $\mathrm{GDP}_{\mathrm{t}}$ total GDP. 
Table 2 shows a significant variation in sector wise FDI in pre-and post-reform period. Sectorial performance index indicate that mining, oil and gas (primary sector) FDI inflow have huge shares in GDP in pre-reform period. The manufacturing sector FDI is comparatively low in post-reform period and services sector FDI share has increased in total GDP. If we consider Indian institutions as social structure governance behavior of individual, then Indian institutional quality may not be encouraging as India have experienced corruption, lack of governance, worse law and order and political instability. Table 3 shows that average Indian institutional quality index is 5.3 in a maximum institutional quality index of 12. Similarly, India ranked low on the institutional quality in all six selected components. The Standard Deviation (SD) of all the six selected components shows that bureaucratic quality is comparatively more stable. Over all Indian institutional quality index is low as compared to other emerging economies.

\section{Literature Review}

Many studies explored that poor institutions reduce FDI by discouraging the foreign investors as Gastanaga, et al. (1998), Campos, et al. (1999), Asiedu and Villamil (2000), Wei (2000), Asiedu (2006) and Srivatav (2006). This point of view is supported by Liu et al., (2021) and pointed out three reasons for this: i) firms productivity is increased by good governance; ii) Cost is increased by poor institution; iii) poor government performance increases uncertainty and risk, which leads to higher vulnerability of firms. Different variables have been used for measurement of the institutional quality impact on FDI inflow. Political risk is one of the proxies used for institutional quality. Aust et al., (2020) and Ali et al (2011) explored political factors as an important factor in FDI inflows. François et al., (2020) found that more FDI is attracted in democratic setup as compared to authoritarian setup government. On other hand Ades and Tella (1999), Ahmad et al., (2003), Alfaro et al., (2005), Asiedu (2002) Atkinson and Brandolini (2001) found that FDI is insignificantly effected by political factors. Other factors for studying the impact of quality institution on FDI are corruption and weak execution contract. Liu et al., (2020) used corruption as proxy of institutional quality and found that FDI inflow is reduced by corruption. According to the study, poor quality of institutions i.e in the economy where corruption level is high, leads to: i) lack of transparency in bureaucracy of domestic country which increases investment opportunity cost; ii) dealing with issues related to bureaucracy high value is given to domestic partners; iii) a decline in investors protectionism lead to decrease their intangible assets; iv) in case of any dispute 
173 between any foreigner investor with his domestic business partner, biased toward local. The 174 negative impact on FDI is confirmed by the study of Fuentelsaz et al., (2020). Jung (2020) concluded that corruption have no effect on FDI. Lakshmi et al., (2021) studied the impact of protectionism of property rights on behavior pattern of multinational companies and found that institutional performance was strongly correlated with FDI ratio to total domestic investment. The property right importance for FDI attraction has been confirmed by the study of Athreye et al., (2021).

Efforts has been made by many researcher for combining various variables of institutional quality. Bahagwati (2007) analyzed different indicators and concluded that government performance, violence and political instability, rules of law and regulatory burden have significant impact on FDI; and voice of accountability factor is insignificant. Globerman and Shapiro (2002) by utilizing data of World Bank, Index of Environmental Sustainability and United Nation Development Program found that for inflow and outflow of FDI governance infrastructure is one of the main variables. Data from International Country Risk Guide (ICRG) used by Uddin et al., (2021) concluded that government performance, violence and political instability, rules of law and regulatory burden have significant effect on FDI inflow. They found that as tax increase cost of production increases, in the same way poor institution increases the business operational cost for foreign investor. Poor institution increases risk and uncertainty which discourage overall investment including FDI. For location of FDI the researchers used a range of institutional factors. First of all they used a set of variables of institution developed by Bonaglia et al.,(2001) like transparency and accountability, non-violence, political stability, government control, no corruption, justice and regulatory quality. Secondly from ICRG database indicator's sub set with expropriation of risk, government stability, no corruption, accountable democracy and justice and law was added. Thirdly the average responses of the country to World Bank survey on the following determinants (i) Courts quality; (ii) Amendments in rules regulations and laws; (iii) Federal government quality; and (iv) Corruption. They found that good quality of institution have statistically significantly positive impact on FDI. Some institutional aspects have greater impact as compared to other. Unpredictable laws, absence of commitment, public policies, extraordinary regulatory burden are important determinants of FDI. Latif (2019) and supported that FDI is positively affected by institutional quality. This study for the first time measured the institutional quality impact on volatility of FDI. The study concluded that the existence of institutional 
determinants of FDI volatility was due to low economic growth, and recommended policy for FDI attraction in domestic economies by offering the "correct" macroeconomic atmosphere which will not be effective without institutional reforms.

\section{Data Collection and Methodology}

\subsection{Data Collection}

To evaluate the association between sectorial FDI and institutional quality during 1986-2019, this research study rely on index of institutional quality (QI), a comprehensive index established on data gathered from International Country Risk Guide (ICRG). The developed index comprises six major variable like, law and order, democratic accountability, investment profile, government stability, corruption and bureaucratic quality in order to insure all the key dimensions of IQ. Institutional quality indicators are highly correlated (Globerman and Shapiro 2002; Brewer (1993) Busse (2004) and it is not possible to include all indicators in a single equation Chaung and Hsu, (2004) Therefore, we construct an institutional quality index using principal component analysis (PCA). The basic purpose of using this technique is to combine the six indicators of institutional quality into a single variable that duplicates the original data with minimal loss of information. In the original form of data sets, diverse scales are employ for institutional factors and certain variables are time invariant. However, after transformation, the only one variable of institutional quality became time variant as presented which is more appropriate for the analysis of time-series data. In order to confirm compatibility among the various measures, entire variables are rescaled from $0-1$ in a way that advanced values denote the robust institutions. Similarly, principal component analysis (PCA) is employed to control the weight given to each component in the devising of the index. This technique is used by Rehman and Ding, (2019) in the development of their economic freedom index. Data on primary sector of FDI inflow (FDIPR), secondary sector of FDI inflow (FDISR), services sector of FDI inflow and aggregated (FDI) inflow are gathered from India statistical year book 2019. Gross fixed capital formation and Merchandise export (current USD) is used as a proxy for domestic investment (DI) and trade openness (TOP) respectively, and collected the data from world development indicators (WDI). Similarly, the data of Human capital index is taken from United Nations development program (UNDP). This study uses infrastructure index which comprises of 30 variables in order to cover entirely the significant dimensions of infrastructure. Additional four sub-indices of infrastructure i.e. communication, 
transport, financial and energy are used to better understand the causal relationship between sectorial FDI inflow and institutional quality in India. Unobserved Components Model (UCM) is employed to determine the weight given to each component in developing the index. Detail about the devising of this global infrastructure is establish in Rehman et al. (2020).

\subsection{Econometrics Methodology}

Jordan \& Philips (2018) introduced an advance version of ARDL model naming, Dynamic Autoregressive Distributed Lag Simulation model. The objective of this model was to overcome the problems of simple ARDL model in estimation in short run and long run model specification. This new model is capable in estimating, stimulating and robotically forecasting of counterfactual alteration in one explanatory variables and its impact on explained variables while holding other control variables constant (Sarkodie et al. 2019); Deaton(1989) and (Jordan and Philips 2018). This model stimulate, estimate and plot graphs of predicted positive and negative variation in the variables automatically and also shows their short run and long run relationship. While Pesran et.al. (2001) ARDL model is limited to estimation of short-run and long-run variables relationship. All variables of this study are integrated at level or first difference i.e I(0) or I(1) and stationary which indicate the applicability of this new dynamic simulated ARDL model. The counterfactual alterations in the explanatory variables and their impact of explained variables are graphically shown in the study. Like earlier studies conducted by Ketteni and Kottaridi (2019); Sarkodie et al. (2019); Jordan and Philips (2018) and Khan et al. (2019b) the results of this new dynamic ARDL error correction equation are as below:

$$
\Delta \ln F D I=\alpha_{0 F D I}+\sum_{i=1}^{p} \psi_{i F D I} \Delta \ln F D I+\sum_{i=1}^{p} \phi_{i F D I} \Delta \ln I Q_{t-i}+\sum_{i=1}^{p} \delta_{i F D I} \Delta \ln T O P_{t-i}+\sum_{i=1}^{p} \varpi_{i F D I} \Delta \ln H C A_{t-i}+\sum_{i=1}^{p} \varpi_{i F D I} \Delta \ln D I_{t-i}
$$

$+\sum_{i=1}^{p} \theta_{F D I} \Delta \ln G I N F+\lambda_{1 F D I} \ln F D I_{t-1}+\lambda_{2 F D I} \ln I Q_{t-1}+\lambda_{3 F D I} \ln T O P_{t-1}+\lambda_{4 F D I} \ln H C A_{t-1}+\lambda_{5 F D I} \ln D I_{t-1}+\lambda_{6 F D I} \ln G N I F_{t-1}$ $+\mu_{1 t}---($ Equation -1$)$

$$
\Delta \ln Q I=\alpha_{0 Q I}+\sum_{i=1}^{p} \psi_{i Q I} \Delta \ln Q I+\sum_{i=1}^{p} \phi_{i Q I} \Delta \ln F D I_{t-i}+\sum_{i=1}^{p} \delta_{i Q I} \Delta \ln T O P_{t-i}+\sum_{i=1}^{p} \varpi_{i Q I} \Delta \ln H C A_{t-i}+\sum_{i=1}^{p} \varpi_{i Q I} \Delta \ln D I_{t-i}
$$

$+\sum_{i=1}^{p} \theta_{Q I} \Delta \ln G I N F+\lambda_{1 Q I} \ln F D I_{t-1}+\lambda_{2 Q I} \ln I Q_{t-1}+\lambda_{3 Q I} \ln T O P_{t-1}+\lambda_{4 Q I} \ln H C A_{t-1}+\lambda_{5 Q I} \ln D I_{t-1}+\lambda_{6 Q I} \ln G N I F_{t-1}$ $+\mu_{1 t}---($ Equation -2$)$ 


\begin{tabular}{|c|c|c|c|c|c|}
\hline \multicolumn{6}{|c|}{ Table 4: Descriptive Statistics } \\
\hline Variables & obs & mean & St.Dev & Min & Max \\
\hline QI & 30 & 0.096 & 1.048 & -1.714 & 1.846 \\
\hline FDIPR & 30 & 117.348 & 147.104 & -3.689 & 564.13 \\
\hline FDISR & 30 & 647.094 & 346.24 & 119.69 & 1483.40 \\
\hline FDITR & 30 & 641.273 & 997.95 & -183.10 & 3859.50 \\
\hline FDI & 30 & 1546.10 & 1482.788 & 271.90 & 5591 \\
\hline TOP & 30 & 0.33 & 0.038 & 0.254 & 0.388 \\
\hline HCA & 30 & 53.59 & 1.38 & 55.21 & 56.60 \\
\hline DIN & 30 & -0.628 & 0.063 & -0.768 & -0.447 \\
\hline GINF & 30 & -0.674 & 0.235 & -1.93 & -0.32 \\
\hline
\end{tabular}

Note; $\Delta$ displays short run, In indicates natural log, $\mu_{1}$ and $\mu_{2}$ express error term, $p$ displays lags of the variable and $\lambda$ shows long run.

\section{Results and Discussions}

Prior to examine the bidirectional effect of institutional quality and sectorial FDI in India, it is very important to observe that the selected variables of the study are stationary at order of first difference $\mathrm{I}(1)$ or level $\mathrm{I}(0)$, if not then the empirical results outcomes will be void. Table 5 shows two different unit root tests results such as augmented dickey fuller (ADF) and Phillip-Perron (PP), were applied to examine the integration order of the selected variables. The results of the Table 4 revealed that all the chosen variables of the current study are integrated and stationary at the order of I(1) and I(0) that approve the method of new dynamic simulated ARDL model, which was developed by Jordan \& Philips (2018). The ARDL model allow to select diverse lags for regressors and regressend. Table 1 shows the results of descriptive statistics. Table 6 show the results of structural break of the data during $1990-2019$. 


\begin{tabular}{|l|c|c|c|c|}
\hline \multicolumn{2}{|c|}{ Table 5: Unit root test results } & \multicolumn{2}{c|}{ DF-GLS Test } \\
\hline & \multicolumn{2}{|c|}{ ADF Test $(1)$} \\
\hline Variables & -1.279 & $-4.395 * * *$ & 1.392 & $-5.128 * * *$ \\
\hline QI & $-5.689 * * *$ & $-5.344 * * *$ & $-5.892 * * *$ & $-5.351 * * *$ \\
\hline FDIPR & -1.483 & $-3.753 * *$ & -1.583 & $-3.935 * * *$ \\
\hline FDISR & -2.551 & $-3.224 * *$ & -2.702 & $-3.368 * * *$ \\
\hline FDITR & -2.852 & $-3.362 * *$ & $-2.971 *$ & $-3.542 * * *$ \\
\hline FDI & -2.402 & $-6.346 * * *$ & -2.538 & $-6.157 * * *$ \\
\hline TOP & $-3.697 * *$ & $-4.425 * * *$ & -2.583 & $-4.948 * * *$ \\
\hline HCA & $-5.578 * * *$ & $-6.383 * * *$ & $-5.803 * * *$ & $-6.38 * * *$ \\
\hline DIN & -1.982 & $-5.358^{* * *}$ & -1.542 & $-5.483 * * *$ \\
\hline GINF & & & & \\
\hline
\end{tabular}

272

Table 6: Zivot-Andrews results

\begin{tabular}{|l|c|c|c|c|}
\hline Variables & $\mathrm{I}(0)$ & Break & $\mathrm{I}(1)$ & Break \\
\hline QI & -2.54 & 2005 & $-4.94 * * *$ & 2000 \\
\hline FDIPR & $-6.345^{* * *}$ & 2003 & $-6.47 * * *$ & 2008 \\
\hline FDISR & -2.73 & 2010 & $-4.54 * *$ & 2007 \\
\hline FDITR & -3.45 & 2008 & $-5.29 * * *$ & 2006 \\
\hline FDI & -3.25 & 2008 & $-5.41 * * *$ & 2012 \\
\hline TOP & -3.11 & 2013 & $-6.52 * * *$ & 2006 \\
\hline HCA & -2.63 & 1998 & $-4.71 * *$ & 2006 \\
\hline DIN & $-5.92 * * *$ & 2009 & $-6.29 * * *$ & 2012 \\
\hline GINF & -2.75 & 2003 & $-4.52 * *$ & \\
\hline
\end{tabular}

273 
274 Before to examine the results of simulated dynamic ARDL bound test, this study uses ARDL bound test

275 for assessing long run relationship in the variables of our interest. The decision of the acceptance or rejection

276 of the null and alternative hypothesis is based upon the F-statistic ${ }^{1}$ results. The existence of long-run

277 relationship in the selected variables of the study is observed that if F-statistic values are greater than lower

278 bounds values (Pesaran et. al. 2001). If the F-statistics values are between the lower and upper bounds

279 values then there will be uncertainty about the decision. ARDL Model is comparatively more useful with

280 that of time series models (Pesaran et al. 2001; Pesaran et al. 1999). For short time period data, the classical

281 ARDL model is used Banerjee (1993) and Dufour and Renault (1998). ARDL model can be applied when

282 variables of the study are integrated at level or first order i.e. I(0) or (1). For statistical analysis of this study,

283 various lags are used for dependent and independent variables. The results of ARDL bound test shows the

284 existence of cointegration among the variables.

285

\begin{tabular}{|c|c|c|c|c|c|c|c|c|}
\hline \multicolumn{9}{|c|}{ QI to aggregated and disaggregated FDI } \\
\hline & \multicolumn{2}{|c|}{$\begin{array}{l}\text { FDI } \\
{[1]}\end{array}$} & \multicolumn{2}{|c|}{$\begin{array}{c}\text { FDISR } \\
{[2]}\end{array}$} & \multicolumn{2}{|c|}{$\begin{array}{c}\text { FDIPR } \\
{[3]}\end{array}$} & \multicolumn{2}{|c|}{$\begin{array}{c}\text { FDITR } \\
{[4]}\end{array}$} \\
\hline Variables & F-stat & ECT & F-stat & ECT & F-stat & ECT & F-stat & ECT \\
\hline FDI/QI & $4.84 *$ & -2.13 & 2.38 & -2.11 & $7.49 * * *$ & -2.49 & $7.67 * *$ & -2.80 \\
\hline FDI/QI/GINF & 3.08 & -2.35 & 1.75 & -3.55 & $5.67 * *$ & -2.51 & $5.27 * *$ & -2.91 \\
\hline FDI/QI/GINF/HCA & $3.86^{*}$ & $\begin{array}{l}- \\
6.21 * * *\end{array}$ & 3.31 & $\begin{array}{l}- \\
5.58 * * *\end{array}$ & $12.51 * * *$ & $\begin{array}{l}- \\
6.14 * * *\end{array}$ & 2.95 & -4.19 \\
\hline FDI/QI/GINF/HCA/TOP & $11.8^{* * *}$ & $\begin{array}{l}- \\
8.75 * * *\end{array}$ & $8.61 * * *$ & $5.42 * * *$ & $9.54 * * *$ & $\begin{array}{l}- \\
6.16 * * *\end{array}$ & $4.43 * *$ & $\begin{array}{l}- \\
7.31 * * *\end{array}$ \\
\hline FDI/QI/GINF/HCA/TOP/DIN & $7.25 * * *$ & $-9.2 * * *$ & $\begin{array}{l}- \\
10.67 * * *\end{array}$ & $4.05 *$ & 4.14 & $\begin{array}{l}- \\
6.16 * * *\end{array}$ & $5.61 * * *$ & $\begin{array}{l}- \\
7.35 * * *\end{array}$ \\
\hline
\end{tabular}

\footnotetext{
${ }^{1}$ Narayan (2005) suggested that Pesaran et.al (2001) narrated critical values are applicable only on large sample size and are not applicable on small sample size.
} 
The Results in Table 7 and 8 display the ARDL bound tests. All the chosen variables utilized in this study are cointegrated as the value of F statistics is higher than the upper bound value at the level of $10 \%, 5 \%$, and $2.5 \%$ level of significance. For long-run relationship, Wald-based bound test is used for empirical estimation in Table 7 and 8, is applied in Equations 1 and 2 in a way that the variables namely, institutional quality, infrastructure, domestic investment, human capital index and trade openness are regularly presented to the cointegration associations between institutional quality and sectorial FDI in India. The significant values of F-statistic in table 7 and 8 accept the alternative hypothesis and reject the null hypothesis. These empirical results suggest a plausible long-run association between sectorial FDI and quality of institutions along with the selected control variables exists. Further, the results shows significant role of infrastructure, domestic investment, human capital index and trade openness in FDI and institutional quality. These results approves the outcomes of Rehman and Ding (2019) and Rehman et al. (2020). The introduction of infrastructure, domestic investment, human capital index and trade openness to the equations significantly augmented the models power.

\begin{tabular}{|c|c|c|c|c|c|c|c|c|}
\hline \multicolumn{9}{|c|}{ Table 8: ARDL Cointegration Bounds test and ECT (-1) } \\
\hline \multicolumn{9}{|c|}{ Aggregated and disaggregated FDI to QI } \\
\hline & \multicolumn{2}{|c|}{$\begin{array}{l}\text { FDI } \\
{[1]}\end{array}$} & \multicolumn{2}{|c|}{$\begin{array}{c}\text { FDISR } \\
{[2]}\end{array}$} & \multicolumn{2}{|c|}{$\begin{array}{c}\text { FDIPR } \\
\text { [3] }\end{array}$} & \multicolumn{2}{|c|}{$\begin{array}{c}\text { FDITR } \\
{[4]}\end{array}$} \\
\hline Variables & F-stat & ECT & F-stat & ECT & F-stat & ECT & F-stat & ECT \\
\hline QI/FDI & $8.32 * * *$ & $-0.78 * * *$ & $7.49 * *$ & -0.28 & 3.48 & -0.37 & 3.48 & -0.28 \\
\hline QI/ FDI /GINF & $5.51^{* *}$ & $-0.78 * * *$ & $4.86 * *$ & -0.24 & 2.26 & -0.38 & 2.26 & -0.34 \\
\hline QI/FDI/ GINF/HCA & $4.37 * *$ & $-0.82 * * *$ & $3.82 *$ & $\begin{array}{l}- \\
0.46 * * *\end{array}$ & 2.16 & $\begin{array}{l}- \\
0.68 * * *\end{array}$ & 2.13 & $\begin{array}{l}- \\
0.26 * *\end{array}$ \\
\hline QI/FDI/GINF/HCA/TOP & $3.62 * *$ & $-0.73 * * *$ & $3.72 *$ & $\begin{array}{l}- \\
0.49 * * *\end{array}$ & $3.9 * *$ & $\begin{array}{l}- \\
0.73 * * *\end{array}$ & $3.99 * *$ & $\begin{array}{l}- \\
0.37 * *\end{array}$ \\
\hline QI/FDI/GINF/HCA/TOP/DIN & 4.94 & $-0.64 * * *$ & $4.71 * *$ & $\begin{array}{l}- \\
0.47 * * *\end{array}$ & $3.42 *$ & $\begin{array}{l}- \\
0.72 * * *\end{array}$ & 2.09 & $\begin{array}{l}- \\
0.46 * *\end{array}$ \\
\hline
\end{tabular}




\begin{tabular}{|c|c|c|c|c|c|}
\hline \multicolumn{6}{|c|}{ Table 9: Diagnostic tests } \\
\hline $\begin{array}{l}\text { Econometric } \\
\text { Problem }\end{array}$ & Test & F-Stat & P-Value & $\begin{array}{l}\text { Null Hypothesis } \\
\text { accepted/rejected }\end{array}$ & Equation No. \\
\hline Serial Correlation & $\begin{array}{l}\text { Breusch- } \\
\text { Godfrey LM }\end{array}$ & 0.786 & 0.468 & accepted & Eq. (1) \\
\hline Heteroscedasticity & $\begin{array}{l}\text { Breusch- } \\
\text { Pagan- } \\
\text { Godfrey }\end{array}$ & 0.291 & 0.612 & Accepted & \\
\hline Specification & $\begin{array}{l}\text { Ramsey } \\
\text { RESET }\end{array}$ & 2.64 & 0.11 & Accepted & \\
\hline Normality & Jarque-Bera & 4.27 & 0.11 & Accepted & \\
\hline Serial Correlation & $\begin{array}{l}\text { Breusch- } \\
\text { Godfrey LM }\end{array}$ & 2.14 & 0.14 & Accepted & Eq. (2) \\
\hline Heteroscedasticity & $\begin{array}{l}\text { Breusch- } \\
\text { Pagan- } \\
\text { Godfrey }\end{array}$ & 2.06 & 0.11 & Accepted & \\
\hline Specification & $\begin{array}{l}\text { Ramsey } \\
\text { RESET }\end{array}$ & 0.03 & 0.85 & Accepted & \\
\hline Normality & Jarque-Bera & 0.128 & 0.93 & accepted & \\
\hline
\end{tabular}

307 This study performs different econometrics tests (such as ARCH, Breusch-Pagan Godfrey, Breush-Godfrey 308 LM, Jarque-Bera and Ramsey RESET), presented in Table 9. These tests were uses to check the reliability 309 of the models'. The empirical result of Breusch Godfrey LM test demonstrated that there is no serial correlations problem in the model. The outcomes of the ARCH and Breusch-Pagan-Godfrey test reveals 311 that, there is no heteroscedasticity problem. Ramsey RESET test results presents that the models is good fit 312 or appropriate, whereas for the normality of the model, Jarque-Bera test is employed, which display that 313 the present model residuals are normally distributed.

314 Although long-run association is only an essential but not a satisfactory condition for causal 315 relationship among the variables (Gupta and Kumar, 2020; Rehman and Ding, 2019). Evidence of 
316 long-run relationship between variables implies that there must be at least unidirectional causality

317 between underling variables without showing the direction of causality (Rehman et al. 2020).

318 Therefore, VECM is estimated in order to identify the direction of long- and short-run causal

319 relationship between institutional quality and FDI. The results of granger causality test reported in

320 Table 10 reveal the short-run and long-run causality from institutional aggregated FDI to

321 institutional quality. The findings indicate that coefficient of error correction term (EC) is

322 significant when FDI, FDIPR, FDISR and FDITR are used as dependent variables. Reversely ECT

323 is also significant when QI is used as a dependent variable (see Table 10, the lower part) These

324 findings suggest that long-run causality exist from FDI (aggregated and disaggregated) to QI and

325 also from QI to FDI which implies that institutional quality matters to attract FDI in primary,

326 services and secondary sectors of India.

\begin{tabular}{|c|c|c|c|c|c|c|c|c|c|}
\hline \multicolumn{10}{|c|}{ Table 10: Granger Causality test results } \\
\hline $\begin{array}{l}\text { Dependen } \\
\mathrm{t} \\
\text { variables }\end{array}$ & \multicolumn{4}{|c|}{ Short run (F-Stat) } & \multicolumn{4}{|c|}{ Long run (ECT) } & $\begin{array}{l}\text { Status } \\
\mathrm{H} 1\end{array}$ \\
\hline \multicolumn{10}{|c|}{ Aggregated FDI to QI } \\
\hline & D.QI & $\begin{array}{l}\text { D.GIN } \\
\text { F }\end{array}$ & D.HCA & $\begin{array}{l}\text { D.TO } \\
\text { P }\end{array}$ & QI & GINF & HCA & TOP & $\begin{array}{l}\text { Accepte } \\
\text { d }\end{array}$ \\
\hline DFDI & 0.33 & 2.27 & $\begin{array}{l}7.497 * * \\
*\end{array}$ & 0.47 & $\begin{array}{l}- \\
0.27 * * \\
*\end{array}$ & $\begin{array}{l}- \\
0.45 * * \\
*\end{array}$ & $\begin{array}{l}- \\
0.44 * * \\
*\end{array}$ & $\begin{array}{l}- \\
0.27 * * \\
*\end{array}$ & $\begin{array}{l}\text { Accepte } \\
\text { d }\end{array}$ \\
\hline \multicolumn{10}{|c|}{ FDIPR to QI } \\
\hline DFDI & 0.035 & 0.67 & $\begin{array}{l}0.951 * * \\
*\end{array}$ & 0.043 & $\begin{array}{l}- \\
0.87 * * \\
*\end{array}$ & $\begin{array}{l}- \\
0.83 * * \\
*\end{array}$ & $\begin{array}{l}- \\
0.80 * * \\
*\end{array}$ & $\begin{array}{l}- \\
0.88 * * \\
*\end{array}$ & $\begin{array}{l}\text { Accepte } \\
\text { d }\end{array}$ \\
\hline \multicolumn{10}{|c|}{ FDISR to QI } \\
\hline$\overline{\text { DFDI }}$ & 1.41 & 1.11 & $4.51 * * *$ & $2.58^{*}$ & $-0.12 * *$ & $-0.13 * *$ & $\begin{array}{l}- \\
0.38 * * \\
*\end{array}$ & $-0.17 * *$ & $\begin{array}{l}\text { Accepte } \\
\mathrm{d}\end{array}$ \\
\hline FDITR $\mathrm{t}$ & & & & & & & & & \\
\hline
\end{tabular}




\begin{tabular}{|l|l|l|l|l|l|l|l|l|l|l|}
\hline DFDI & 0.77 & 1.95 & 1.53 & 0.28 & $\begin{array}{l}- \\
0.30 * * \\
*\end{array}$ & $\begin{array}{l}- \\
0.27 * * \\
*\end{array}$ & $\begin{array}{l}- \\
0.52 * * \\
*\end{array}$ & $\begin{array}{l}- \\
0.28^{* *} \\
*\end{array}$ & $\begin{array}{l}\text { Accepte } \\
\mathrm{d}\end{array}$ \\
\hline QI to Aggregated FDI (Reverse causality) & & & \\
\hline
\end{tabular}

329 Table 11 display the empirical results of a simulated ARDL - dynamic model. The simulated 330 ARDL - dynamic model can estimate, stimulate, and also plot to forecast negative and positive 331 changes graphs, happening in the variables robotically as well as their long- and short-run 332 associations (See Figures 1 and 2). These all are the benefit of novel simulated ARDL - dynamic 333 over initial version of ARDL. Because the classical version of ARDL can alone evaluate the short334 and long-run relationships of the selected variables. These all are the benefit of novel simulated 335 ARDL - dynamic over initial version of ARDL. The empirical results of a simulated ARDL 336 dynamic model are showed in table 8. The empirically evaluated outcomes in table 8 confirmed 337 that institutional quality significantly positively affect aggregated and disaggregated FDI inflow 338 in short- and long run in Indian economy. The present empirical results are consistent with idea 
339 that Institutional quality is interesting for foreign investor because it deceases implementation cost

340 and make doing business easy in host countries. While, poor institutions impede FDI and can act

341 like a tax, thus increasing the cost of FDI (Camarero et al., 2021). Investors are unwilling to invest

342 in countries where institutions encourage corruption, nepotism and red tape because these factors

343 increase the cost of doing business (Cicatiello et al., 2021) (Rehman et al. 2020a, Rehman et al.

344 2019). The results of other regressors i.e., infrastructure, domestic investment, human capital and

345 trade openness increase all the sector of FDI like primary, secondary and services in long as well

346 as in short run in China. These results are in the line of Rehman and Ding (2019), Rehman et al.

347 (2020b) and Rehman and Noman, (2020c).

\begin{tabular}{|c|c|c|c|c|}
\hline \multicolumn{5}{|c|}{ Table 11: Asymmetric impact of QI on disaggregated and aggregated FDI } \\
\hline Variables & $\begin{array}{l}\text { FDI } \\
{[1]}\end{array}$ & $\begin{array}{l}\text { FDIPR } \\
{[2]}\end{array}$ & $\begin{array}{l}\text { FDISR } \\
{[3]}\end{array}$ & $\begin{array}{l}\text { FDITR } \\
{[4]}\end{array}$ \\
\hline \multicolumn{5}{|c|}{ SR dynamics } \\
\hline D.lnFDI & $0.421 * *$ & 0.164 & 0.138 & 0.201 \\
\hline D. $\ln Q \mathrm{I}$ & $0214 * *$ & 0.101 & 0.393 & 0.458 \\
\hline D.lnHCA & $5.58 * * *$ & $1.302 *$ & $7.34 *$ & $-8.83^{*}$ \\
\hline D.lnTOP & $6.47 *$ & 11.29 & \begin{tabular}{|l|}
3.1 \\
\end{tabular} & 5.4 \\
\hline D.lnGINF & $3.47 *$ & 3.68 & 8.26 & $6.51 *$ \\
\hline D.lnDI & $-3.68 * *$ & -2.79 & 12.64 & -11.51 \\
\hline \multicolumn{5}{|c|}{ LR dynamics } \\
\hline $\operatorname{lnFDI}$ & $0.69^{* *}$ & $0.207^{*}$ & $3.24 * * *$ & $1.54 * * *$ \\
\hline $\ln I Q$ & $-0.87 * *$ & $2.38 * * *$ & $10.27 * * *$ & $7.75 * * *$ \\
\hline lnGINF & $0.93 * *$ & $0.65^{*}$ & $0.386^{*}$ & 0.19 \\
\hline $\operatorname{lnTOP}$ & $4.35^{* *}$ & $10.58^{* * *}$ & $12.86^{* * *}$ & $10.37 * * *$ \\
\hline $\operatorname{lnHCA}$ & 35.53 & $10.35^{* *}$ & $47.47 * * *$ & $56.49 * * *$ \\
\hline $\operatorname{lnDI}$ & 1.36 & -0.83 & 5.67 & -4.27 \\
\hline Constant & $-21.94 * * *$ & $-66.82 * * *$ & $-31.21 * *$ & $-43.53 * * *$ \\
\hline
\end{tabular}




\begin{tabular}{|l|l|l|l|l|}
\hline F-test PSS & $7.28 * * *$ & $3.27 * *$ & 1.21 & 2.85 \\
\hline Obs & 34 & 34 & 34 & 34 \\
\hline R Square Adj. & 0.901 & 0.932 & 0.893 & 0.912 \\
\hline Asymmetry statistic & \multicolumn{5}{|l|}{} \\
\hline Asymmetries SR & $0.412^{*}$ & $0.141^{*}$ & $8.52^{* * *}$ & 0.013 \\
\hline Asymmetries LR & $5.23^{* * *}$ & $1.93^{*}$ & $1.45^{*}$ & $1.92^{*}$ \\
\hline
\end{tabular}

Fig. 1 Response of export diversification to $10 \%+/$ - shock in lnIQ

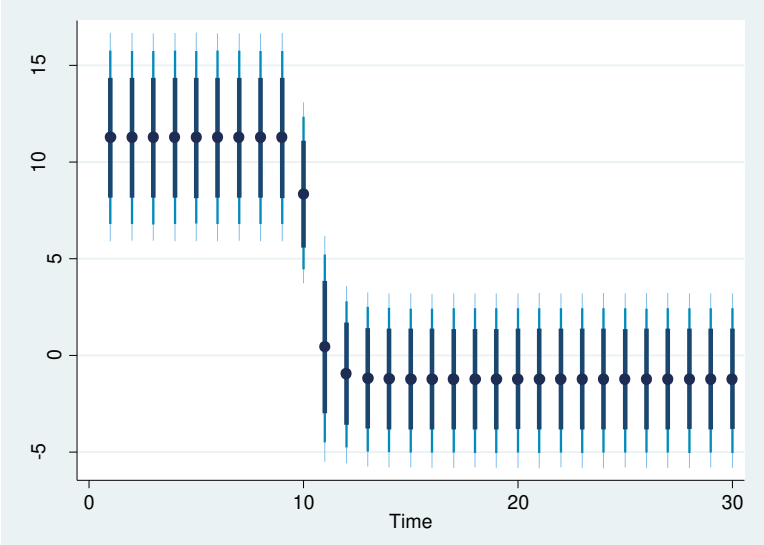

$-10 \% \operatorname{lnIQ}$

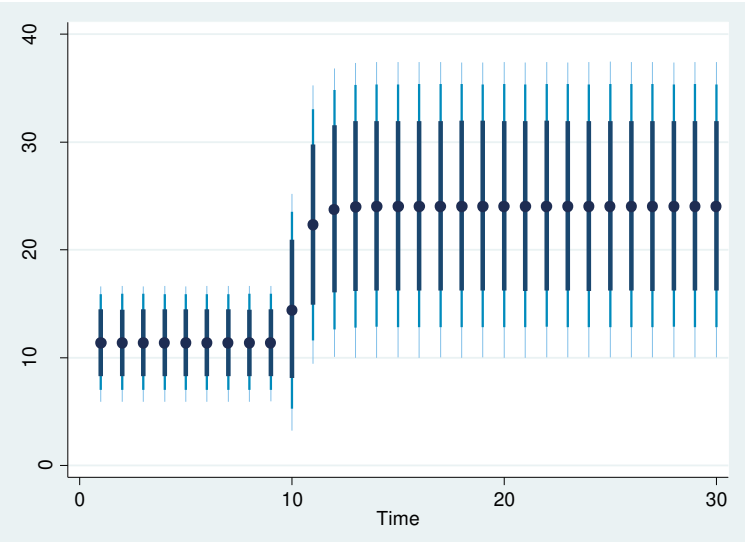

$-10 \% \operatorname{lnIQ}$

Table 12 shows the effect of aggregated and disaggregated FDI on Indian institutional quality. The empirically evaluated outcomes confirmed that the aggregated and disaggregated FDI inflow significantly positively effects institutional quality in the long run. The present empirical results

354 are similar to the idea that FDI positive role in economics has turned a self-evident truth where 355 technological, saving and investment gape is covered by foreign firm through provision of 356 technology and cash to the recipient economy. FDI provide opportunity to local firms for learning 357 from foreign firms either by doing with these firms are watching and infuse a sense of competition 358 in local firms and institutions that boost the productivity as whole in the host country. Nam (2020) 359 suggests that competition in attracting FDI have positive contribution in FDI aspirant countries 
and call prodigious positive change FDI and introduce to rival recipient countries as ' race to the top'. FDI not only transfer innovation in productive technology, but it also improves the institution quality which contribute to domestic economy (Rehman et al. 2020a, Rehman et al. 2019). The results of other control variables i.e., human capital, domestic investment, infrastructure and trade openness effect quality of institutions significantly and positively. These results are in the line of Rehman and Ding (2019), Rehman et al. (2020b) and Rehman and Noman, (2020c) in long as well as in short run in China. The $\mathrm{ECT}_{\mathrm{t}-1}$ values in the upper half of table 5 presents fast adjustment to equilibrium by export diversification.

\begin{tabular}{|c|c|c|c|c|}
\hline \multicolumn{5}{|c|}{ Table 12: Asymmetric impact of disaggregated and aggregated FDI on QI } \\
\hline Variables & $\begin{array}{l}\text { FDI } \\
{[1]}\end{array}$ & \begin{tabular}{|l} 
FDIPR \\
{$[2]$}
\end{tabular} & $\begin{array}{l}\text { FDISR } \\
{[3]}\end{array}$ & $\begin{array}{l}\text { FDITR } \\
{[4]}\end{array}$ \\
\hline \multicolumn{5}{|c|}{ SR dynamics } \\
\hline D. $\ln Q \mathrm{I}$ & $0.251^{* *}$ & $0.35^{* *}$ & $0.17^{*}$ & $0.45^{*}$ \\
\hline D. $\operatorname{lnFDI}$ & $0.217 * *$ & $0.451 * *$ & $0.151^{*}$ & \begin{tabular}{|l|}
0.290 \\
\end{tabular} \\
\hline D.lnHCA & $13.86^{*}$ & $1.126^{* * *}$ & $4.16^{* *}$ & $7.56^{* * *}$ \\
\hline D. $\ln \mathrm{TOP}$ & $3.12^{*}$ & $1.56^{*}$ & $2.56^{* *}$ & 0.46 \\
\hline D.lnGINF & $0.1106^{*}$ & $0.0218^{*}$ & 0.013 & 0.04 \\
\hline D.lnDI & 0.164* & $0.26^{*}$ & 0.05 & -0.25 \\
\hline \multicolumn{5}{|c|}{ LR dynamics } \\
\hline $\operatorname{lnFDI}$ & $0.576^{* * *}$ & $0.073^{*}$ & $0.364 * *$ & $0.703 * *$ \\
\hline $\operatorname{lnQI}$ & $0.578 * * *$ & $0.618 * *$ & $0.295^{*}$ & 0.085 \\
\hline lnGINF & $0.045^{*}$ & $0.165 * *$ & 0.086 & 0.035 \\
\hline $\operatorname{lnTOP}$ & $6.07 * *$ & $12.124 * * *$ & $6.865^{* *}$ & $4.270^{* * *}$ \\
\hline $\operatorname{lnHCA}$ & $20.86^{* *}$ & 10.57 & 13.265 & \begin{tabular}{|l|}
37.54 \\
\end{tabular} \\
\hline $\operatorname{lnDI}$ & 0.165 & 1.369 & 0.175 & \begin{tabular}{|l|}
1.058 \\
\end{tabular} \\
\hline
\end{tabular}




\begin{tabular}{|l|l|l|l|l|}
\hline Constant & $78.85^{*}$ & $21.05^{* *}$ & $-21.63^{* *}$ & $-20.56^{* *}$ \\
\hline F-test PSS & 1.178 & 2.35 & 0.92 & 1.07 \\
\hline Obs & 34 & 34 & 34 & 34 \\
\hline R Square Adj. & 0.88 & 0.83 & 0.76 & 0.75 \\
\hline Asymmetry & & & \\
\hline
\end{tabular}

Asymmetry statistic

\begin{tabular}{|l|l|l|l|l|}
\hline Asymmetries SR & 0.065 & 0.635 & 1.043 & 0.789 \\
\hline Asymmetries LR & $4.72 * * *$ & 0.163 & $2.53 * *$ & $3.65^{* *}$ \\
\hline
\end{tabular}

370 Fig. 2. Response of export sofistication to $10 \%+/$ - shock in aggregated and disgreegred FDI respectively

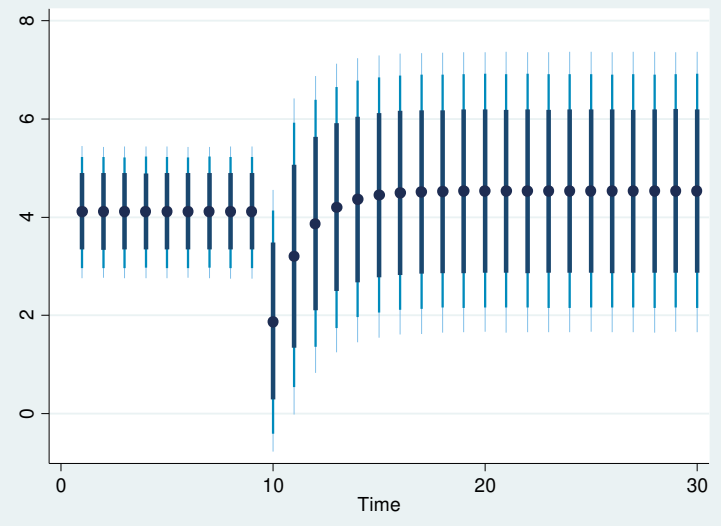

$371-10$ aggregated FDI

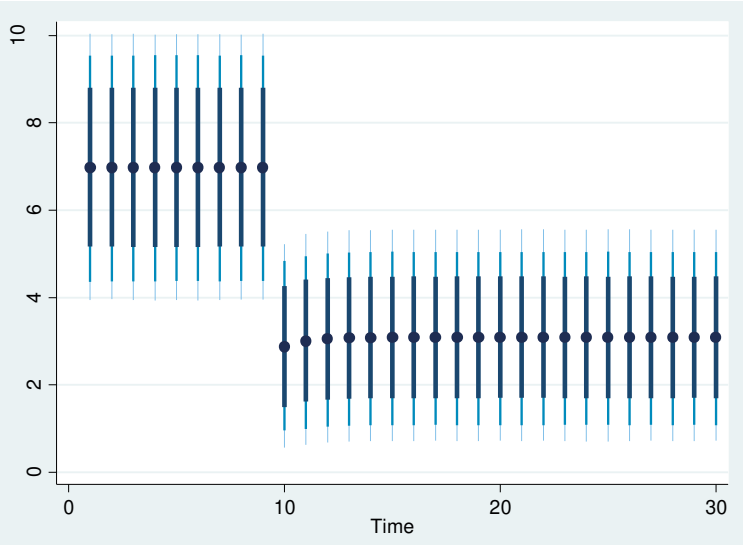

$372-10$ Primary FDI

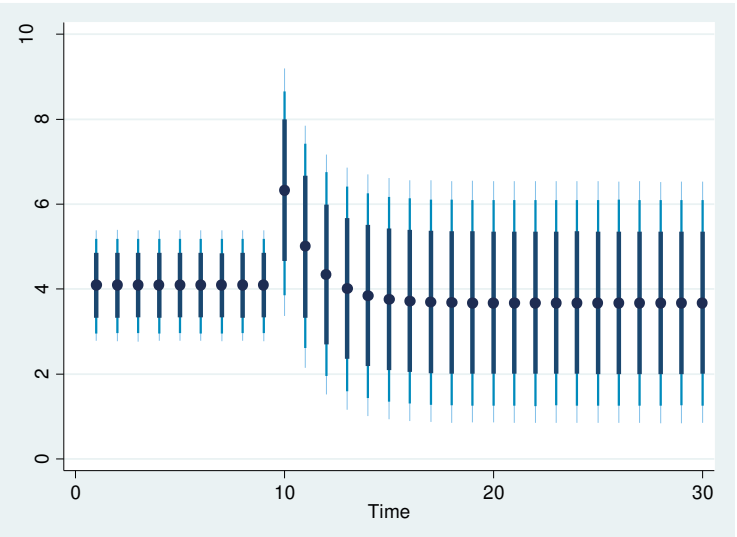

-10 aggregated FDI

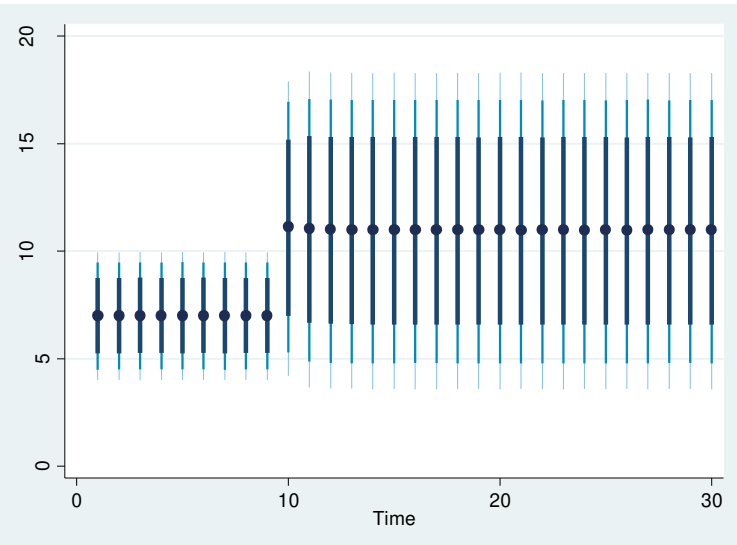

-10 Primary FDI 


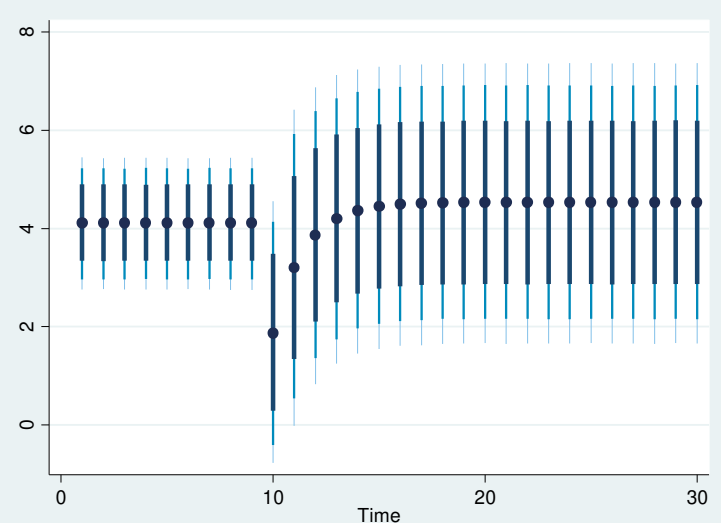

$373-10$ Secondary FDI

374

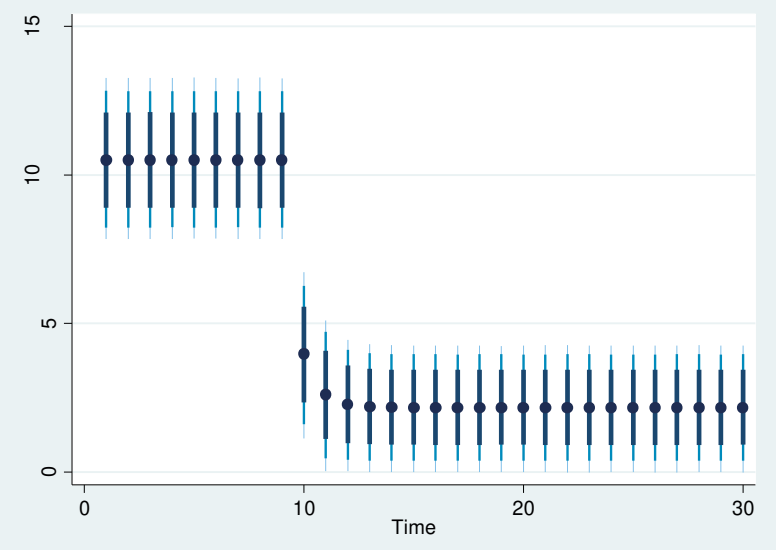

$375-10$ Services FDI

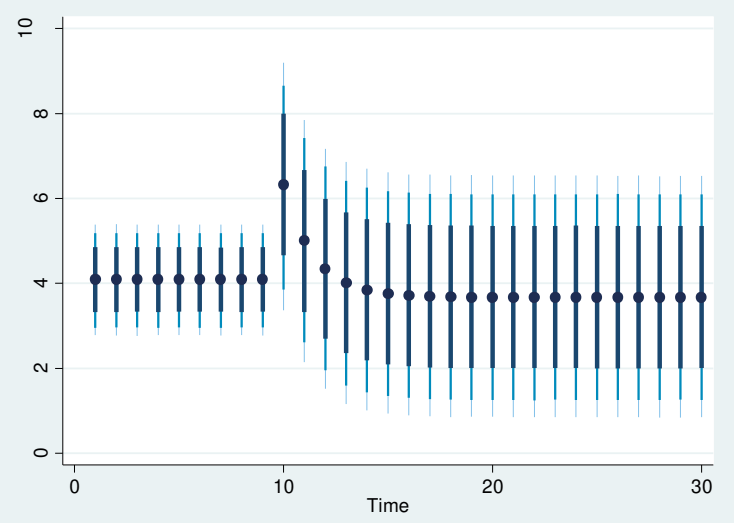

-10 Secondary FDI

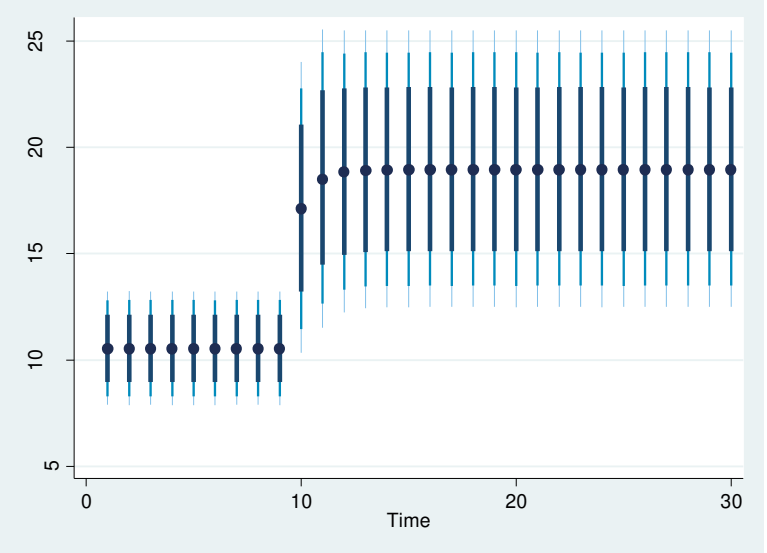

-10 Services FDI

\section{7. Conclusion and Policy Implication}

377 Inadequate institutions deteriorate market connectivity, it puts hindrances in reaping trade

378 potential, create frictions in market and impose unnecessary delay, and thus increases the overall 379 cost of production, which adversely affect FDI inflow in home economy. Poor quality of 380 institutions adversely affects the comparative edge of an economy while the availability of good 381 quality of institutions improves its comparative advantage, both on international as well as on 382 domestic fronts. Economies with adequate institutions play significant role in attracting FDI while 383 countries with deteriorating institutions play less than desirable role in attracting FDI inflow and 384 economic integration. 
We used a new simulated ARDL dynamic approach on annual data from 1986-2019 to examine the long as well as short-run association of institutional quality with FDI. The empirical results of the present study verified that the significant causal relationship between institutional quality and aggregated and disaggregated FDI inflow. The empirical outcome of the study suggests that quality of institutions attract FDI inflow in India (i.e. institutional quality have significant and positive effect on aggregated and disaggregated FDI inflow in short-run and long-run). Reversely, FDI inflow improves quality of institutions (like, law and order, domestic accountability, investment profile, bureaucratic quality, political stability and corruption). This is interesting news for policymakers in India who want to catchup on advanced economies and reduce the gap between India and developed economies, particularly in attracting FDI inflow. These empirical outcomes also negate the claim of Nayyar and Mukherjee (2020) that Indian firms do not depend on quality of domestic institutions. Rather, the result shows that quality of institutions today in India are more skill intensive and confident, and thus to encourage the development of domestic firms could be an effective way to improve the rate of FDI inflow in India. Besides the main variables, the control explanatory variables like, infrastructure, domestic investment, human and trade openness have also positive and significant effect on the aggregated and disaggregated FDI inflow and quality of institutions, which means to maintain the open and reform policy and to further develop the quality of institutions system are also important for the advancement of FDI attraction in India.

\section{Declarations:}

Ethics approval and consent to participate

Not Applicable

Consent for publication

Not Applicable

Authors' contributions

FUR is the principal author of this article. EA revised the manuscript and made changes accordingly, i.e., provided theoretical justification and origin \& justification of econometric model. KS has provided supervisional services. All authors read and approved the final manuscript.

Acknowledgements

Not Applicable

Authors' information (optional)

Laboratory of International and Regional Economics, Graduate School of Economics and Management, Ural Federal University, Russia. Department of Economics, Kohat University of Science and Technology, Kohat, Pakistan 


\section{Funding}

Not Applicable

Availability of data and materials

Not Applicable.

\section{Competing interests}

The authors declare that they have no competing interests. Furthermore, this article does not contain any study with animal performed by the author.

\section{References}

Ades, A., and R. Di Tella. 1999. "Rents, Competition, and Corruption." American Economic Review 89: 982-993.doi:10.1257/aer.89.4.982.

Ahmad, M. H., M. S. Butt, and S. Alam. 2003. "Foreign Direct Investment, Exports and Domestic Output in Pakistan." Pakistan Development Review 42: 715-723.

Alfaro, L., S. Kalelmi-Ozcan, and V. Volosovych. 2005. Capital Flows in a Globalised World: The Role of Policies and Institutions. NBER Working Papers No. 11696. Cambridge, MA: NBER.

Ali, F., N. Fiess, and Ronald M. (2011). "Climbing to the Top? Foreign Direct Investment and Property Rights.’Economic Inquiry 49: 289-302. doi:10.1111/j.1465-7295.2010.00319.x.

Antonietti R. and Franco C.,(2021) From FDI to economic complexity: a panel Granger causality analysis, Structural Change and Economic Dynamics, Volume 56, Pages 225-239, https://doi.org/10.1016/j.strueco.2020.11.001.

Asiedu, E., \& A, Villamil. (2000). Discount Factors and Thresholds: Foreign Investment when Enforcement is Imperfect', Macroeconomic Dynamics, 4(1): 1-21.

Asiedu, E., (2006). Foreign Direct Investment in Africa: The Role of Natural Resources, Market Size, Government Policy, Institutions and Political Instability, working paper, United Nations University

Asiedu, E. 2002. "On the Determinants of Foreign Direct Investment to Developing Countries: Is Africa Different?” World Development 30: 107-119. doi:10.1016/ S0305-750X(01)00100-0.

Athreye S., Saeed A. and Baloch M.S.,(2021) Financial crisis of 2008 and outward foreign investments from China and India, Journal of World Business, https://doi.org/10.1016/j.jwb.2021.101190

Atkinson, A. B., and A. Brandolini. 2001. "Promise and Pitfalls in the Use of 'Secondary' Data Sets: Income Inequality in OECD Countries as a Case Study." Journal of Economic Literature 39: 771-799. doi:10.1257/jel.39.3.771. 
Aust V., Morais A. I.and Pinto I.,(2020) How does foreign direct investment contribute to Sustainable Development Goals? Evidence from African countries, Journal of Cleaner Production, Volume 245, https://doi.org/10.1016/j.jclepro.2019.118823

Azzimonti M.,(2019) Does partisan conflict deter FDI inflows to the US?, Journal of International Economics, Volume 120, Pages 162-178, https://doi.org/10.1016/j.jinteco.2019.06.001.

Banerjee, A. 1993. Co-Integration, Error-Correction, and the Econometric Analysis of NonStationary Data. Oxford:Oxford University Press.

Bhagwati, J. N. 2007. In Defence of Globalization. New York: Oxford University Press.

Bonaglia, F., J. B. de Macedo, and M. Bussolo. 2001. How Globalization Improves Governance, OECD Development Center Technical Paper No. 181, OECD, Paris.

Brewer, T. L. 1993. "Government Policies, Market Imperfections, and Foreign Direct Investment." Journal of International Business Studies 24: 101-120. doi:10.1057/palgrave. jibs.8490227.

Busse, M. 2004. "Transnational Corporations and Repression of Political Rights and Civil Liberties: An Empirical Analysis.” Kyklos 57: 45-65. doi:10.1111/kykl.2004.57.issue-1.

Cai H., Boateng A. and Guney Y., (2016) Host country institutions and firm-level R\&D influences: An analysis of European Union FDI in China, Research in International Business and Finance, Volume 47, Pages 311-326, https://doi.org/10.1016/j.ribaf.2018.08.006

Camarero M., Moline rS. and Tamarit C.,(2021) Japan's FDI drivers in a time of financial uncertainty. New evidence based on Bayesian Model Averaging, Japan and the World Economy, Volume 57, https://doi.org/10.1016/j.japwor.2021.101058.

Campos, J.E., Lien, D., \& Pradhan, S. (1999). The Impact of Corruption on Investment: Predictability Matters, World Development, 27 (6), 1059-67.

Challe E., Lopez J. I. and Mengus E.,(2019) Institutional quality and capital inflows: Theory and evidence, Journal of International Money and Finance, Volume 96, Pages 168-191, https://doi.org/10.1016/j.jimonfin.2019.05.005.

Cicatiello L., Simone E.D., Ercolano S. and Gaeta G. L.,(2021)Assessing the impact of fiscal transparency on FDI inflows,Socio-Economic Planning Sciences, Volume 73, https://doi.org/10.1016/j.seps.2020.100892.

Contractor J. F, Nuruzzaman N., Dangol R. and Raghunath S., (2021). How FDI Inflows to Emerging Markets Are Influenced by Country Regulatory Factors: An Exploratory Study, Journal of International Management, Volume 27, Issue 1, https://doi.org/10.1016/j.intman.2021.100834

Deaton, A. 1989. Saving in Developing Countries: Theory and Review. Working Paper, Department of Economics, Princeton University.

Donghua Chen D., Xin Yu X. and Zhou Zhang Z.,(2019) Foreign direct investment comovement and home country institutions, Journal of Business Research, Volume 95, Pages 220-231, https://doi.org/10.1016/j.jbusres.2018.10.023. 
Dufour, J.-M., and E. Renault. 1998. "Short Run and Long Run Causality in Time Series: Theory." Econometrica 66: 1099-1125. doi:10.2307/2999631.

Economou F.,(2019) Economic freedom and asymmetric crisis effects on FDI inflows: The case of four South European economies, Research in International Business and Finance, Volume 49, Pages 114-126, https://doi.org/10.1016/j.ribaf.2019.02.011

François A., Panel S. and Weill L.,(2020) Educated dictators attract more foreign direct investment, Journal of Comparative Economics, Volume 48, Issue 1, https://doi.org/10.1016/j.jce.2019.11.006.

Forte R. and Moura R., (2013). The effects of foreign direct investment on the host country's economic growth: theory and empirical evidence. The Singapore Economic Review vol. 58, no. 03, 1350017 (2013)

Fuentelsaz L., Garrido E. and Maicas J.P.,(2020) The effect of informal and formal institutions on foreign market entry selection and performance, Journal of International Management, Volume 26, Issue 2, https://doi.org/10.1016/j.intman.2020.100735.

Gupta, S., Kumar, N. Time varying dynamics of globalization effect in India. Port Econ J (2020). https://doi.org/10.1007/s10258-020-00190-4

Gastanaga, V., Nugent, J.,\& Pashamiova, B. (1998). Host Country Reforms and FDI Inflows: How Much Difference Do They Make? World Development 26(7), 1299-1314.

Globerman, S., and D. Shapiro. 2002. "Global Foreign Direct Investment Flows: The Role of Governance Infrastructure." World Development 30: 1899-1919. doi:10.1016/S0305750X(02)00110-9.

Heavilin J. and Songur H.,(2020) Institutional distance and Turkey's outward foreign direct investment, Research in International Business and Finance, Volume 54,https://doi.org/10.1016/j.ribaf.2020.101299.

Jordan S, Philips AQ (2018) Cointegration testing and dynamic simulations of autoregressive distributed lagmodels. Stata J 18(4):902-923

Jung J.,(2020) Institutions and Telecommunications Investment, Information Economics and Policy, Volume 50, https://doi.org/10.1016/j.infoecopol.2020.100849

Junjian Gu J.,(2021) FDI characteristics, industry homogeneity, and audit fees in Japanese multinationals, Journal of Multinational Financial Management, https://doi.org/10.1016/j.mulfin.2021.100678.

Lakshmi G., Saha S. and Bhattarai K.,(2021) Does corruption matter for stock markets? The role of heterogeneous institutions, Economic Modelling, Volume 94, Pages 386-400, https://doi.org/10.1016/j.econmod.2020.10.011. 
Kellard M. N. , Kontonikas A. , Lamla M.J., Maiani S., Wood G.,(2020) Risk, financial stability and FD Journal of International https://doi.org/10.1016/j.jimonfin.2020.102232.

Money and Finance,

Ketteni E. and Kottaridi C.,(2019) The impact of regulations on the FDI-growth nexus within the institution-based view: A nonlinear specification with varying coefficients, International Business Review, Volume 28, Issue 3, Pages 415-427, https://doi.org/10.1016/j.ibusrev.2018.11.001

550

551

552

553

Kottaridi C., Giakoulas D. and Manolopoulos D., (2019) Escapism FDI from developed economies: The role of regulatory context and corporate taxation, International Business Review, Volume 28, Issue 1, Pages 36-47, https://doi.org/10.1016/j.ibusrev.2018.06.004

Latif H.A.,(2019) FDI response to political shocks: What can the Arab Spring tell us?, Journal of Behavioral and Experimental Finance, Volume 24, https://doi.org/10.1016/j.jbef.2019.07.005

Liu H., Islam M. A., Khan M. A., Hossain M.I. and Pervaiz K.,(2020) Does financial deepening attract foreign direct investment? Fresh evidence from panel threshold analysis, Research in International Business and Finance, Volume 53,https://doi.org/10.1016/j.ribaf.2020.101198.

Liu M., Marshall A. and McColgan P.,(2021)Foreign direct investments: The role of corporate social responsibility,Journal of Multinational Financial Management, Volume 59, https://doi.org/10.1016/j.mulfin.2020.100663.

Nam J., Sesay J.B., Wynne K. and Zhang G.,(2020) Financial efficiency and accounting quality: The impact of institutional micro-factors on FDI, Journal of Policy Modeling, Volume 42, Issue 2, Pages 451-465, https://doi.org/10.1016/j.jpolmod.2019.12.004.

Narayan, P. K. 2005. "The Saving and Investment Nexus for China: Evidence from Cointegration Tests.” Applied Economics 37: 1979-1990. doi:10.1080/00036840500278103

Pesaran, M. H., Y. Shin, and R. J. Smith. 2001. "Bounds Testing Approaches to the Analysis of Level Relationships.” Journal of Applied Econometrics 16: 289-326. doi:10.1002/jae.616.

Piteli L.E.N, Kafouros M. and Pitelis C. N.,(2021) Follow the people and the money: Effects of inward FDI on migrant remittances and the contingent role of new firm creation and institutional infrastructure in emerging economies, Journal of World Business, Volume 56, Issue 2, https://doi.org/10.1016/j.jwb.2020.101178

Slesman L., Abubakar Y. A. and Mitra J.,(2020) Foreign direct investment and entrepreneurship: Does the role of institutions matter?, International Business Review, https://doi.org/10.1016/j.ibusrev.2020.101774

Reddy K. S.,(2019) Pot the ball? Sovereign wealth funds' outward FDI in times of global financial market turbulence: A yield institutions-based view, Central Bank Review, Volume 19, Issue 4, Pages 129-139, https://doi.org/10.1016/j.cbrev.2019.08.003

Rehman, F. U., A. A. Noman, and D. Yibing. 2020b. ““'Does Infrastructure Increase Exports and Reduce Trade Deficit in Selected South Asian Countries?" by Using a New Global Infrastructure 
Index." Journal of Economic Structures 9(1). Article No. 10(2020). doi:10.1186/s40008-0200183-x.

Rehman, F. U., A. A. Noman, and M. A. Khan. 2020d. "China's Outward Foreign Direct Investment and Exports Diversification: An Asymmetric Analysis." Journal of Chinese Economic and Foreign Trade Studies. doi:10.1108/JCEFTS-12-2019-0065.

Rehman, F. U., and D. Khan. 2015. "Determinants of Food Price Inflation in Pakistan: An Econometric Analysis." Advances in Economics and Business 3 (12): 571-576. doi:10.13189/ aeb.2015.031205.

Rehman, F. U., D. Yibing, A. A. Noman, and M. A. Khan. 2020c. "The Nexus between Infrastructure and Export: An Empirical Evidence from Pakistan." Global Journal of Emerging Market Economies 1-17. doi:10.1177/0974910120930529.

Rehman, F. U., M. A. Khan, M. A. Khan, K. Pervaiz, and I. Liaqat. 2020a. "The Causal, Linear and Nonlinear Nexus between Sectoral FDI and Infrastructure in Pakistan: Using a New Global Infrastructure Index." Research in International Business and Finance 52 (4): 101129. doi:10.1016/j.ribaf.2019.101129.

Rehman, F. U., and Y. Ding. 2019. "The Nexus between Outward Foreign Direct Investment and Export Sophistication: New Evidence from China." Applied Economics Letters. doi:10.1080/ 13504851.2019.1616056.

Ryan W. Tang W.R.,(2021) Pro-market institutions and outward FDI of emerging market firms: An institutional arbitrage logic, International Business Review, https://doi.org/10.1016/j.ibusrev.2021.101814

Rehman F. U, NomanA., A., Yibing D., (2020b). "Does Infrastructure Increase Exports and Reduce Trade Deficit in Selected South Asian countries?" By Using a New Global Infrastructure Index, Journal of Economic Structures, Vol. 9 Article No. 10 (2020) https://doi.org/10.1186/s40008-020$\underline{0183-\mathrm{X}}$

Sarkodie SA, Strezov V,Weldekidan H, Asamoah EF, Owusu PA, Doyi INY (2019) Environmental sustainability assessment using dynamic autoregressive-distributed lag simulations - nexus between greenhouse gas emissions, biomass energy, food and economic growth. Sci Total Environ 668:318-332

Srivatav S., (2006). The role of foreign direct investment in India's services exports: an empirical investigation The Singapore Economic Review vol. 51, no. 02, pp. 175-194

Soh K. L., Wong W. P. and Tang C.F.,(2021) The role of institutions at the nexus of logistic performance and foreign direct investment in Asia, The Asian Journal of Shipping and Logistics, https://doi.org/10.1016/j.ajs1.2021.02.001

Tag M.N.,(2021) Judicial institutions of property rights protection and foreign direct investment inflows, International Review of Law and Economics, Volume 65, https://doi.org/10.1016/j.irle.2020.105975. 
621 Uddin M., Chowdhury A., Zafar S., Shafique S. and, Jia Liu J.,(2019) Institutional determinants 622 of inward FDI: Evidence from Pakistan, International Business Review, Volume 28, Issue 2, Pages 623 344-358, https://doi.org/10.1016/j.ibusrev.2018.10.006

624 Wang L. H., Lin C. H., Fung H. G. and Kao T.C.,(2019) Foreign direct investment and downside 625 risk: Evidence from Taiwan, Pacific-Basin Finance Journal, Volume 57, 626 https://doi.org/10.1016/j.pacfin.2019.01.010.

627 Wei, S.J. (2000). How Taxing is Corruption on International Investors?', Review of Economics 628 and Statistics, 82 (1), 1-11. World Investment Report. (2011). Non-Equity Modes of International 629 Production and Development, UNCTA 
Figures

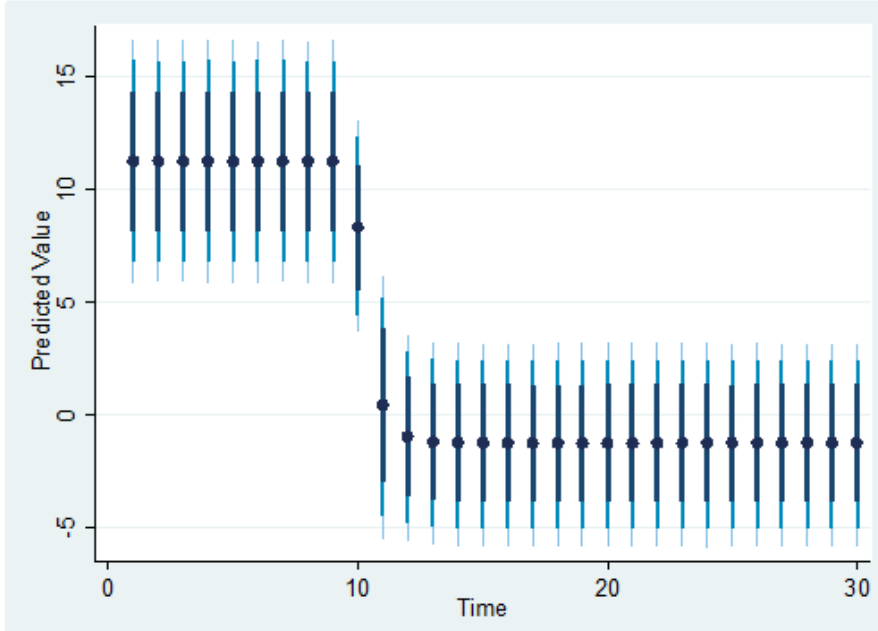

$-10 \% \operatorname{lnIQ}$

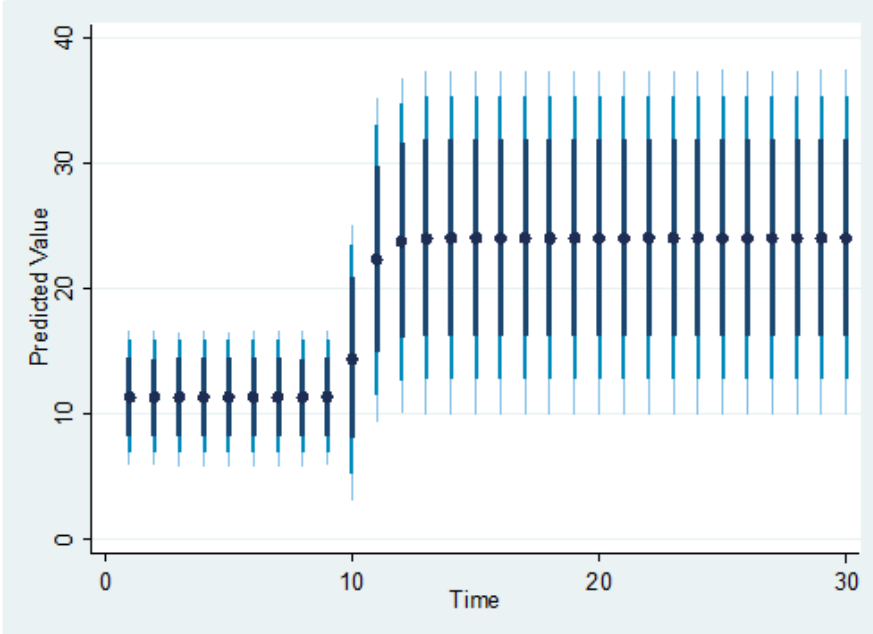

$-10 \% \operatorname{lnIQ}$

Figure 1

Response of export diversification to $10 \%+/$ - shock in InIQ

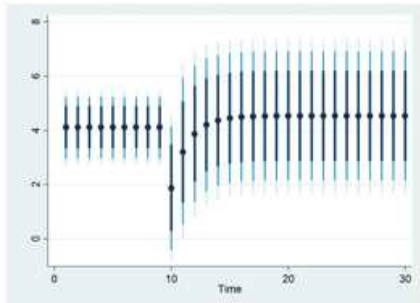

-10 aggregated FDI

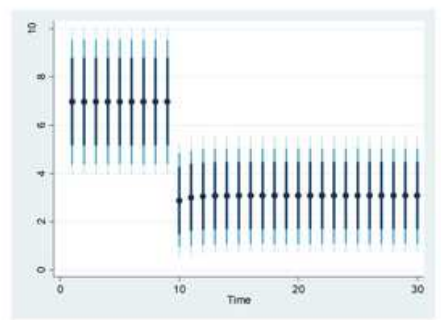

-10 Primary FDI

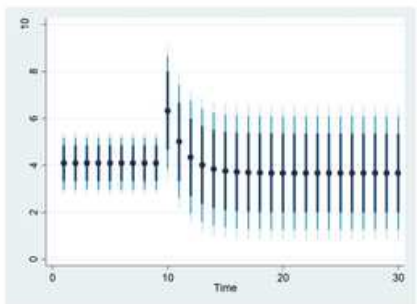

-10 aggregated FDI

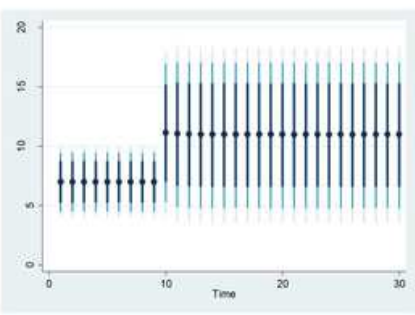

-10 Primary FDI

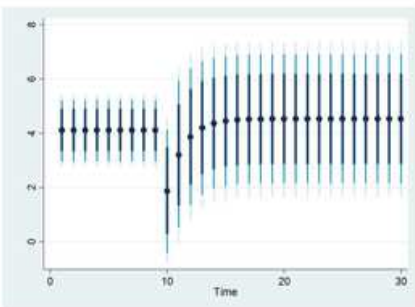

-10 Secondary FDI

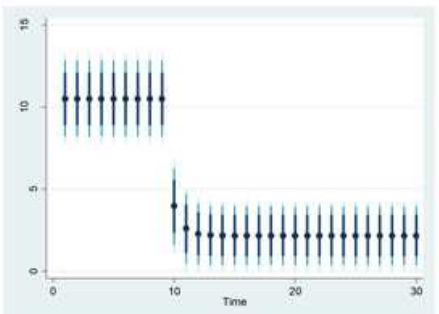

-10 Services FDI

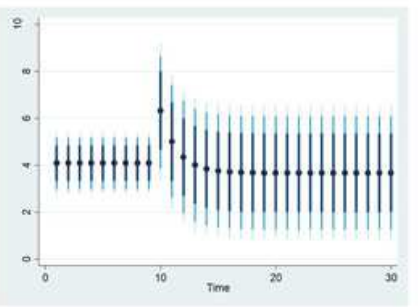

-10 Secondary FDI

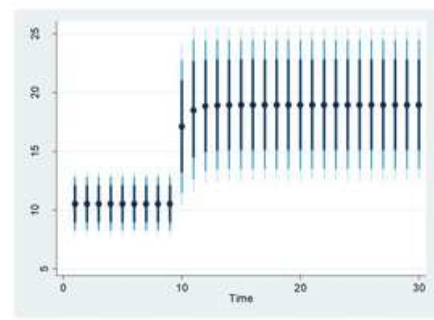

-10 Services FDI

Figure 2

Response of export sofistication to $10 \%+/$ - shock in aggregated and disgreegred FDI respectively 